\title{
Modernist Medievalism and the Expressionist Morality Play: Georg Kaiser's From Morning to Midnight
}

\author{
Leanne Groeneveld \\ University of Regina (Canada) \\ E-mail: Leanne.Groeneveld@uregina.ca
}

\begin{abstract}
This article examines the modernist medievalism of Georg Kaiser's From Morning to Midnight (Von morgens bis mitternachts), discussing the influence of the morality play genre on its form. The characterization and action in Kaiser's play mirrors and evokes that of morality plays influenced by and including the late-medieval Dutch play Elckerlijc and its English translation as Everyman, in particular Hugo von Hofmannsthal's Jedermann, first produced in Berlin in 1911. The medievalism of Kaiser's play is particularly evident when it is compared to Karl Heinz Martin's film version of the text, produced in 1920. The play's allegory and message, though contemporary, are less specifically historically contextual than the film's, while its central protagonist is more representative of generic capitalist subjectivity. The detective film shapes Martin's adaptation, obscuring the morality play conventions and therefore medievalism of Kaiser's earlier text.
\end{abstract}

Keywords: Modernism, Expressionism, Medievalism, morality play.

Many early twentieth-century avant-garde modernisms were, at least to some degree, medievalisms: that is, they referenced and reimagined European medieval systems of knowledge, belief, and aesthetics in their contemporary art. Theatre artist and sometime surrealist Antonin Artaud famously pronounced in his 1927 Manifesto for a Theatre that Failed that he believed "the Revolution most urgently needed consists of a kind of regression into time. Let us return to the mentality or even simply to the way of life of the Middle Ages, but really and by a kind of essential metamorphosis, and then I shall consider that we have accomplished the only revolution worth talking about” ${ }^{1}(1988,162)$.

1 "La Révolution la plus urgente à accomplir est dans une sorte de régression dans le temps. Que nous en revenions à la mentalité ou même simplement aux habitudes de vie du Moyen Age, mais réellement et par une manière de métamorphose dans les essences, et j'estimerai alors que nous aurons accompli la seule révolution qui vaille la peine qu'on en parle” (Artaud 1961, 25). 
Expressionist visual artist Georg Grosz saw significant similarities between early twentieth-century and late medieval culture. In a 1931 radio interview, he compared the two eras: "I consider that the present time is similar to the final epoch of the Middle Ages. It seems as though we are standing at the beginning of a new world view, a new interpretation of everything. To put it more clearly, the ground we are standing on is fiery, cracked, and shaking, as it must have seemed to the painters at the end of the Middle Ages" (qtd. in Flavell 1988, 68). In Grosz's opinion, medievalism offered an appropriate modernist response to the challenges of early twentieth-century history and culture.

In Germany, many avant-garde artists adopted and adapted technologies and forms employed in the middle ages: for example, inspired by the work of medieval illustrators, Expressionist visual artists experimented with woodcut, producing contemporary images with what they considered medieval European technology. Many sculptors imitated the work of medieval carvers: Ernst Ludwig Kirchner's prototype for a larger sculpture Iron Blacksmith (Eiserner Schmied) was lauded by patron Karl Ernst Osthaus and University of Jena professor of archaeology and art history Botho Graef for its medieval style; according to Graef, medieval art was "the prime expression of the Nordic-German spirit" (Goebel 2008, 66, as well as 68, fig. 10). Other of Kirchner's sculptures - for example Farmer with Cow (Bauer mit $K u$, 1925) (Henze 2007, 152, ill. 14) - resemble carvings found in the choirs and on the ceilings of medieval churches. And Kirchner's colleague Herman Scherer's 1924 Lamentation of the Dead (Totenklage) intentionally evokes the late medieval pieta (Henze 2007, 168, cat. 140).

Expressionist dramatists also looked to the European Middle Ages for inspiration. Oscar Kokoschka ironically referenced medieval romance in his horrifying Murderer, the Women's Hope (Mörder Hoffnung der Frauen, 1909); Georg Kaiser dramatized a fourteenth-century incident from the Hundred Years' War in his The Burghers of Calais (Die Bürger von Calais, 1914); and August Stramm evoked both medieval hagiography and nineteenth-century Gothicism in his Sancta Susanna (1921). As these and other theatre artists dramatized medieval subject matter and referenced various medieval visual arts in their texts, they also imitated particular medieval dramatic genres, the most often acknowledged being German mystery and Passion plays. A genre less often noted for its influence on the Expressionists, and therefore the focus of this paper, was the medieval morality play, an allegorical form dramatizing the experiences of a universal or typical protagonist tempted into sin and recalled to redemption and salvation over the course of the play's action. Most familiar to German playwrights and audiences 
in the example of Hugo von Hofmannsthal's 1911 Jedermann, a revision of the form (in particular of the late medieval Dutch and English plays Elckerlijc and Everyman) for contemporary German audiences, the morality play was adopted and adapted in part or in whole by a number of Expressionist playwrights, who found its central assumptions, characteristics, and goals consistent with their own aesthetics. ${ }^{2}$ As will be discussed, the clearest example of such a reimagining of the form was Georg Kaiser's From Morning to Midnight (Von morgens bis mitternachts). This play dramatizes the plight of an early twentieth-century Everyman, a bank cashier whose fall from "grace" into sin leads him on a modernist - therefore ultimately unsuccessful - quest for salvation.

A desire for social and aesthetic renewal, even revolution, inspired modernist medievalisms. Wary of claims that technology would solve the problems facing their nations before, during, and after the First World War, modernists tended to question the value of empirical knowledge collected and disseminated and aesthetic techniques utilized since the European Renaissance, sometimes regarding that knowledge and those techniques as unimportant or uninteresting, other times regarding them as dangerous and corrupting. Expressionists in particular suspected that the so-called European enlightenment of the eighteenth century had produced a host of artistic and social ills: the privileging of reason over imagination, a general overdependence on sight and devaluing of other sensory experiences, the privileging of the object in the world over subjective human experience, the disconnection of the human from the spiritual, the individuation of identity - and as a result of all these, the individual's harmful separation from the collective and alienation from his or her true spiritual and physical self. To heal both rifts, the Expressionists believed they needed to reconnect with preenlightenment cultures: the classical or the medieval. The European Middle Ages represented for them at once the height and childhood of European culture; if they could reconnect and become inspired by the medieval, they might start again from a point of particular understanding and insight.

It is important to stress that the Expressionists did not advocate a simple return to the medieval but rather called for a medievalist perspective in their aesthetics and in their art. The terms medieval, medievalism, and medievalist are as distinct from one another as are the more familiar terms modern, modernism, and modernist. The adjective modern identifies an historical period while the noun

2 Robert Potter offers Kaiser's Gas plays, Toller's Masse Mensch (Masses and Man), and Čapek's $R U R$ as examples of texts likely influenced by the morality form, although he does not analyse them in any detail $(1975,231)$. 
modernism and adjective modernist identify a group of particular philosophies and aesthetics within that period, or, in other words, particular understandings and representations of that contemporary (modern) world. Medieval similarly identifies an historical period, in Western Europe that beginning with the fall of the Roman Empire in the late fifth century and ending at the beginning of the sixteenth century. Medievalism and medievalist identify something else: again, understandings and representations of the culture of the medieval period, but, in most uses of these terms, within and from the perspective of another time and culture. A particular medievalism is a particular understanding of and practice inspired by medieval cultural products encountered and interpreted at an historical and cultural distance. The nineteenth century, for example, was marked by profound cultural interest in the Middle Ages and by cultural products that could be described as medievalist: Alfred Lord Tennyson's Lady of Shalott and Idylls of the King, Sir Walter Scott's Ivanhoe, and William Morris's Arts and Crafts movement to name a few famous English examples. Participants in various medievalisms have been and are to varying degrees conscious of this distance and of the fact that they are interpretations, not reality. Despite Antonin Artaud's apparent call for the medieval to be restored, modernist medievalisms did not naively advocate a return to another, long-past era and culture but rather advocated the adoption and adaptation by modernist theory and practice of what were regarded to be medieval aesthetics, subject matter, and artistic forms. Modernists advocated the translation of these aesthetics, subjects, and forms into modernist idioms.

In the case of the morality play, aspects of the medieval genre compatible with Expressionist philosophies, politics, and aesthetics were adopted while those that were not were discarded or altered. Extant medieval examples of the morality play, an international form, differ considerably; however, theatre historians generally agree that plays belonging to this genre display certain shared characteristics and goals. Robert Potter has suggested that the "events which occur on stage in the course of the [morality] play are not mimetic representations of life, but analogical demonstrations of what life is about” $(1975,33)$. As Pamela King describes them, moralities "offer their audiences moral instruction through dramatic action that is broadly allegorical. Hence they are set in no time, or outside historical time, though their lack of historical specificity is generally exploited by strategically collapsing the eternal with the contemporary. The protagonist is generally a figure of all men, reflected in his name, Everyman or Mankind, and the other characters are polarised as figures of good and evil. The action concerns alienation from 
God and return to God, presented as the temptation, fall and restitution of the protagonist” (King 2008, 235).

As for their central message or effect, Clifford Davidson argues that "phenomenologically, man is encouraged by these plays to see his life as wounded and in need of healing, or as unnaturally separated from the sources of all health and well being" $(1989,11)$. In Expressionist morality plays, the instruction or central message differs in some respects, as audience members are encouraged to break with old beliefs (for example, in God) and traditional institutions (for example, the church) and to reject conventional values for revolutionary humancentred ethics. However, Expressionist plays are allegorical in their replacement of individual characters with types; their settings or given circumstances are not naturalistic and are therefore to some degree universal or outside of time. Also, their central themes and motifs of human regeneration and transformation and their recognition of the individual's wounded state and need for healing easily harmonize with medieval morality prototypes.

Possibly the most well-known example of a medieval morality play is the Netherlandish text Elckerlijc (1496), more famous in translation as the English play Everyman (c. 1510-1525). These very closely related plays feature (somewhat unusually) a central character who has already fallen into sin and from the beginning is in need of salvation/transfiguration. Because characters and plot events will be important to understanding Kaiser's Expressionist text, a brief summary of Elckerlijc/Everyman will be offered here. In both plays, God sends Death (Doot) to tell Everyman that he will soon die and will need to make a pilgrimage and a reckoning of the deeds he committed while alive. Everyman tries to bribe Death for a slight delay; unsuccessful, he then asks if he may bring someone along with him on his final pilgrimage. Death jokes that he certainly may if he can find anyone "so hardy" (Davidson 2007, 25, 1. 157) ("so koene" [ 2007, 24, 1. 136]) to undertake the journey. Everyman first approaches the characters Fellowship (Gheselscap), Kindred (Maghe), and Cousin (Neve) and asks them to join him. All three refuse when they learn where Everyman is going. He next approaches his Goods (Tgoet), who informs Everyman that he cannot move because he has been so closely guarded, fettered and chained by Everyman over his lifetime, and that it would be better for Everyman to travel alone, since love of Goods and of money first led him into sin.

At this point in the play Everyman hears his Good Deeds (Duecht) crying. She tells Everyman she would happily go with him to judgement but cannot because his sins have bound her and have made her so weak that she cannot move. She 
tells Everyman to ask her sister Knowledge (Kennisse) for advice. Knowledge appears and advises Everyman to approach the holy man Confession (Biechte), which he does, repenting his sins and undertaking acts of penance. Everyman's actions gradually release Good Deeds, making her mobile and able to accompany him on his journey. Everyman then calls on his Five Wits (Vijf Sinnen), Beauty (Schoonheyt), Strength (Cracht), and Discretion (Vroetscap), and together they begin his final pilgrimage. Ultimately, in sequence, all abandon him at the lip of his grave; only Good Deeds descends with him into the earth. At the play's conclusion, Everyman's soul is raised from the grave by an angel and transported into the "hevenly spere [sic]" (Davison 2007, 77, l. 899) ("Hemels pleyne" [Davison 2007, 76, 1. 852]), his final redemption achieved.

Many adaptations and translations of Elckerlijc/Everyman were produced and circulated in Europe in the century after its initial composition and performance. Christiaan de Stercke published a Latin version of the play entitled Homulus in 1536; in 1539, Joris Langvelt produced a nominally Protestant Latin adaptation entitled Hekastus; and Thomas Kirchmeyer produced an "out-and-out Protestant" Latin version entitled Mercator in 1540 (Conley 1985, 11-12). These versions in their turn inspired further translations and adaptations. Jaspar von Gennep published a Low German version of Homulus (also drawing on Hekastus) in 1540, entitled Everyman, the Wages of Sin is Death (Homulus, Der sunden loin ist der Toid). Hans Sachs based his A Comedy of the Dying Rich Man (Ein comedi von dem reichen sterbenden menschen) (1549) on Langvelt's Hekastus. Johannes Stricker published The German Gourmand (De Düdesche Schlomer), influenced by both Homulus and Hekastus, in 1584. And Kirchmeyer's Mercator was translated into "French, Polish, Czech, and Russian as well as Dutch and High German” in the sixteenth century (Conley 1985, 12).

Expressionist playwrights including Kaiser could have been familiar with the original late medieval Elckerlijc, with its English translation Everyman, and/or with any of its many other adaptations and translations. A celebrated and long remembered revival of the English play at the turn of the twentieth century could and likely would have drawn their attention to the morality play as form. In 1901, Everyman was revived by the actor and theatrical manager William Poel for the Elizabethan Stage Society. This production premiered at the Charterhouse in London in July, was remounted at University College, Oxford in August, and was performed again at St. George's Hall, London in May of 1902. A month-long engagement followed at the Imperial Theatre, and the play toured throughout the United Kingdom that same year. Under Poel's former partner in 
the venture, Ben Greet, Everyman subsequently travelled to the United States, touring extensively in that country in 1903 (Speaight 1954, 161-168; Potter 1975, 222-225; Schreiber 1975, 99-100).

According to Robert Potter, "Poel's production had made Everyman a contemporary fact, and the morality play a part of the twentieth century" (Potter 1975, 225), powerfully influencing early twentieth-century English, American, and European writers. In Germany, the production's impact can be traced through Max Reinhardt, who, as Robert Speaight first noted, attended the Elizabethan Stage Society's early performances of the play in 1901 (Speaight 1954, 165). Two years after witnessing this production, Reinhardt met the playwright Hugo von Hofmannsthal; likely not coincidentally, that same year Hofmannsthal began composition of his own morality play entitled Jedermann (Stevens 1973, 118). Acknowledged by the playwright to be an adaptation of Everyman and the previously mentioned A Comedy of the Dying Rich Man by Hans Sachs, Jedermann was produced for the first time by Reinhardt at the Zirkus Schumann in Berlin on 1 December 1911. This production then toured, with performances in Munich, Dresden, and Vienna (Stevens 1973, 129). Expressionist and other playwrights in Germany who had missed the Everyman revival and were not familiar with the morality play in any other form would have found it difficult to avoid news of Hofmannsthal's play and Reinhardt's production. Potter has suggested that Jedermann in fact "familiarized the German-speaking world with the abstract concept of morality characterizations," asserting further that "its influence was felt in the avant-garde drama of its own day which we now call Expressionism" (1975, 231).

Jedermann modifies and adds to the basic plot and characters of its sources and inspirations. Like Elckerlijc/Everyman it begins, in a considerably shortened section of the action, with God (Got) commanding Death (Tod) to call Jedermann on his final pilgrimage. Jedermann enters, proudly contemplating his possessions. He sends his Steward (Vogt) to collect a bag of gold needed to purchase a pleasure garden and tells him also to summon the Cook (Koch), whom he instructs to prepare a sumptuous feast for friends and family. The Steward re-enters with Jedermann's gold as his Friend (Gesell) and a Poor Neighbour (Armer Nachbar) arrive separately. The Poor Neighbour asks for alms; Jedermann initially refuses but later relents, offering him a single penny. The Poor Neighbour grumbles but accepts the meagre gift and leaves the stage. A Debtor (Schuldknecht) on his way to prison asks Jedermann to tear up a complaint the richer man has made against him. Jedermann refuses and the Debtor is taken away. 
Jedermann's Mother (Jedermanns Mutter) arrives, foretells her own death, warns Jedermann that he too will die, and laments his bachelorhood. Jedermann protests that he is still too young to worry about dying as he is only forty years old but reluctantly promises his mother that she will live to see him married. Jedermann's Paramour (Buhlschaft) then enters the scene. The banquet Jedermann called for earlier in the play magically appears, a sumptuously-dressed table rising up from the floor. As Jedermann, his Paramour, and their guests sit to eat, Jedermann presages his own death, suggesting his guests will be able to pay their last respects to him at the feast. He then wonders how his Paramour would react if she were told he was to die within the hour and asks if she would remain his companion in death. The others discuss how to lift his melancholia - with hot wine, magical potions; they call for music and sing to distract him. Jedermann's mood lifts temporarily, but as his cousin sings, he hears a bell tolling off in the distance. The sound eventually disappears and he feels momentarily cheered. But Jedermann next hears a jumble of voices calling his name. The room grows dim and Death appears, informing Jedermann that God requires he settle his final account. Jedermann protests that he is ill-prepared, that he needs another twelve years to be ready to face God, but Death informs him that he must make his pilgrimage without delay. Jedermann asks for one additional day, night, and then hour to prepare his soul and to find a companion to accompany him on his journey. Death tells him he will not find anyone willing to travel along but before leaving allows him a short reprieve, warning Jedermann to use his time wisely. Jedermann first approaches his Friend, who initially promises to do anything for him, even to accompany him to hell, but breaks his promise upon learning where Jedermann is travelling. Next, Jedermann approaches his Fat and Thin Cousins (Dicker and Dunner Vetters), who refuse to leave with him when they learn the nature of his journey. Jedermann then calls for his Steward and other servants to collect together his money, which he decides must be carried with him on his pilgrimage. They bring a heavy chest out on stage but flee when they see Death appear to chastise Jedermann for wasting the extra time he has been given and failing to understand how to find a proper companion. Left alone, Jedermann panics and vows that he will not leave without his money. At this moment Mammon springs out of the chest and asks Jedermann what is troubling him. Jedermann tells Mammon that he has been summoned by God and orders Mammon to accompany him on his journey; Mammon refuses, explaining that he is comfortable where he is. Jedermann objects that Mammon is his property and must do as he wishes, a claim that makes Mammon laugh. In fact, Mammon 
explains, Jedermann has been his servant, his Jumping Jack (Hampelmann) all along (Hofmannsthal 1957, 71). Mammon will remain on earth while Jedermann must pass away. Mammon retreats back inside his chest.

At this moment Good Deeds (Werke) calls feebly to Jedermann from a pallet. He initially ignores her, thinking she is calling for help or charity. When she identifies herself and offers to travel with him, he laments the life he has lived and the fact that his actions have made his Good Deeds so weak and ill. She advises him to speak to her sister Faith (Glaube), who then enters the scene. Faith is initially skeptical that Jedermann merits assistance and interrogates him on the articles of faith; eventually persuaded of his contrition, she reminds him of God's mercy when he despairs. A monk appears in the distance; Faith tells Jedermann that this holy man can help purify his soul. Jedermann falls to his knees, then prostrates himself in prayer. His mother enters the stage on her way to mass; she tells her servant that she hears angelic music. Before exiting, she claims that this music signifies her son has been saved and she can now die confident that she will meet him again in heaven. Good Deeds casts away her crutches, and Faith informs Jedermann that, no longer burdened by his sins, both sisters can now accompany him on his way. Jedermann rejoices and leaves the stage to be absolved by the monk. Just after he exits, a Devil (Teufel) enters to collect Jedermann's soul, but Faith, Good Deeds, and an Angel prevent the Devil from accosting him. After complaining about the injustice of Jedermann's long, sinful life and quick deathbed repentance, the Devil exits the stage in frustration. Jedermann then reenters carrying a pilgrim's staff and dressed in a long white robe. Good Deeds accompanies him into the grave as Faith watches and angels sing.

Georg Kaiser's From Morning to Midnight (Von morgens bis mitternachts) bears more than a passing resemblance to Hofmannsthal's Jedermann and to its sources, and exhibits many characteristics of the generic morality play. The text's date of composition is uncertain: Kaiser claimed he wrote the play in 1912; however, Rhys Williams has noted Kaiser's tendency to predate compositions and suggests the text could have been revised or even written as late as $1915(1988,365)$. As it was published for the first time in 1916, only a terminus post quem and terminus ante quem for its composition can be identified. The earliest possible completion would still date the play to the year following Reinhardt's December 1911 production of Jedermann in Berlin, the same year it toured Munich, Dresden, and Vienna. Although Kaiser was not living in any of those cities at that time - he was in Seeheim-on-the-Bergstrasse and Weimar (Schürer 1971, 14) - according to Cynthia Walk he "regularly visited Berlin and frequented the cultural life of 
the city" $(2007,180)$. Kaiser then could have seen Reinhardt's production of Jedermann or at very least could have heard or read about Hofmannsthal's play before or while composing his own text.

Kaiser's interest in medieval history and aesthetics was likely in part sparked and shaped by the ideas of socio-anarchist philosopher Gustav Landauer. Rhys Williams has argued that the two shared a "mutual respect and admiration" and that a "fruitful interaction between Landauer and Kaiser can be dated very early in Kaiser's development as a dramatist, at least as early as From Morning to Midnight [...]" (1988, 365). Williams describes Landauer as "a profound enthusiast of the Middle Ages, though no uncritical medievalizing thinker" (1988, 366). "Like many influential figures in the early years of the century," Williams writes, Landauer saw "the medieval world as the high point of Western Culture, from which there has been a steady decline" (1988, 366). Landauer's admiration for the Middle Ages stemmed from his belief that Geist - as he described it, a "bridge of love between individuals" (Maurer 1971, 78), "a natural, not an imposed compulsion" (qtd. in Maurer 1971, 78), and as such "the necessary basis of culture in a nation" (Williams 1988, 366) - found its clearest active expression in medieval European Christianity. Christianity as a type of Geist "[permeated] all the social organizations of the medieval period and [wielded] the diverse human functions into a cultural unity" $(1988,366)$ - but did so only when expressed through the establishment of "freely-determined mutual relationships" within communities and not through state-mandated hierarchies and beliefs or through the imposition of orthodoxy and dogma $(1988,366)$. Williams suggests "there are hints here of the idealization of the medieval village community, self-sufficient and operating by barter, producing only what the community needs" $(1988,368)$. Landauer advocated the creation "within capitalist society [of] socialist communities which operate according to this pattern, and he ends his treatise [here Aufruf zum Sozialismus (Call to Socialism)] with a call to his audience individually to join such communities, withdraw their support in practical terms from capitalist society, and put into practice the idea of a socialism free from the state" $(1988,368)$.

Williams has persuasively argued that the action of From Morning to Midnight was influenced by Landauer's philosophies. The play dramatizes the central protagonist's slow discovery that money has no intrinsic value and that its use leads to broken and unfulfilling familial and communal relationships. I would add here that the play's medievalism extends beyond its idealization of pre-capitalist medieval social structures to its form: its action also mirrors and evokes that of earlier morality plays, particularly those plays belonging to the Elckerlijc family 
tree. Williams notes but does not explore the central character's role in the play as a "kind of modern Everyman, taking upon himself the sins of the capitalist world and becoming its sacrificial victim" $(1985,372)$. Other critics have similarly commented on the play as morality without exploring the significance of its chosen genre. In an anthology of Kaiser's plays in translation, J. M. Ritchie in his introduction describes the text's protagonist as a "modern Everyman caught up in the dilemmas of contemporary life" $(1971,7)$. Carole Jane Lambert, in a more extended analysis of the play's medieval themes, allusions, numerology, and symbolism, suggests that Kaiser's use of flat characters in general "resembles medieval allegory and morality plays where each character represents only one trait such as Gluttony, Lust, Greed” (1986, 244). She too considers Kaiser's central character an Everyman (266), one "disillusioned, rejected, and betrayed" (1986, 274), but fails to compare his actions to those of the protagonists in Kaiser's potential sources.

Like Elckerlijc/Everyman/Jedermann, Kaiser's protagonist, the Kassierer or Cashier, is a "figure representing all of humanity:" he is a man typical of his particular profession but also representative of a general early twentieth-century capitalist subjectivity, embedded in a system of monetary exchange, lacking any notion of personal identity outside of that system. He therefore also embodies a broader early twentieth-century aesthetic and spiritual human inauthenticity. At the beginning of the play, the Cashier lacks self-awareness and functions more or less as the early twentieth-century equivalent of a bank machine, taking money from and dispensing money to patrons of the bank who embody vices and virtues: for example, the rich, pompous Fat Man (Herr) and the humble Maid Servant (Dienstmädchen). As Williams describes him, the Cashier is an "automaton, wholly submerged in his function" (1985, 369); "he accepts the conventional relationship between money and what it can buy without question, even unthinkingly, confining himself to the purely mechanistic role as a minor functionary in the capitalist economy" $(1985,369)$. His connection to money establishes a link between him and the characters Elckerlijc/Everyman/ Jedermann, who all believe they own and control their Goods, not that their Goods own and control them. This misunderstanding of their agency in relation to capital comes to the Cashier after his theft of money from the bank. When an exotic Florentine Lady (Dame) approaches his counter and accidentally touches the Cashier's hand, he becomes newly conscious and his senses become engaged. The Cashier steals 60000 marks from the bank, flees, and embarks on a journey, an Expressionist variation on Everyman's pilgrimage. 
The Cashier first travels to the Lady's hotel room, hoping to persuade her to accompany him on his travels (the Lady here resembles Jedermann's Paramour). He is rebuffed, as she has come to town to help her son purchase a long-lost erotic painting by Lucas Cranach of Adam and Eve in the Garden before the Fall, and so he sets off alone except for his money. Pausing under a tree, the Cashier contemplates his next move; shifting snow exposes a hulking figure - a skeleton resembling and representing Death $(T o d)$ - and the Cashier briefly considers committing suicide. But because he still has money to spend and various accounts to settle, he asks Death to return for him again around midnight.

The Cashier next travels home. There he finds his Mother (Mutter), Wife (Frau), and Daughters (Töchter), female equivalents of Kindred and Cousin in Elckerlijc/ Everyman and the Thin and Fat Cousins in Jedermann. One of his daughters plays the piano, attempting to please him with music (the Overture to Tännhauser) while his Wife offers to fry chops for his dinner. The Cashier decides that the women represent nothing more than oppressive bourgeois responsibilities and petty, distracting pleasures, rejects their company, and moves on. Arriving next at a sports palace, a public arena full of crowds enjoying a six-day cycle race, the Cashier offers excessive prize money to the exhausted athletes, hoping to whip the spectating crowds into a frenzy. The crowds respond for a time but eventually hush with respect at the arrival of the king; the Cashier, disgusted by their deference, leaves. The Cashier then brings his ill-gotten goods to a nightclub where he hopes to distract himself, orders a final banquet of champagne and spitzen, and meets four masked women. After discovering the first is drunk, the second and third are not pretty, and the fourth is missing a leg, he abuses them and flees: like Jedermann, he is only temporarily distracted by women, alcohol, and music. In the final scene of the play, the Cashier attends a Salvation Army meeting where sinners are called publicly to confess and repent (recalling Elckerlijc's/Everyman's encounter with the holy man Confession and Jedermann's meeting with Faith and his absolution offstage by the Monk). Here the Cashier realizes something that Everyman, Elckerlijc, and Jedermann learn very early on in their plays - that his Goods, his money, will not be the means of his salvation but rather of his damnation. The Cashier discards what remains of the 60000 marks he stole from the bank, throwing the money into the crowd of Salvation Army officers and penitents, who madly scoop it up. The police arrive to arrest the Cashier, tipped off by the Salvation Army Girl (Mädchen), the equivalent of Knowledge, Faith, or perhaps even Good Deeds, who earlier called the Cashier to repent and now will collect a reward for betraying him. Death appears again 
in the form of a skeleton, manifesting in the wiring of a chandelier above the Cashier's head. The Cashier pulls a gun from his coat, shoots himself, and falls back against the Salvation Army cross sewn onto a backing curtain. Kaiser's stage directions tell us the Cashier's “dying cough sounds like an 'Ecce' - his expiring breath like a whispered - 'Homo'” (Ritchie 1971, 73) ("Sein Ächzen Büstelt wie ein Ecce - sein Hauchen surrt wie ein Homo” [1919, 120]).

Kaiser's adaptation of the morality form here is obvious, as are the similarities between his play and Elckerlijc, Everyman, and Jedermann. The Cashier first highlights his representative function when he visits the Lady in her hotel room; he sees the medieval painting she wishes to buy for her son and recognizes himself in the figure of Adam, telling the Lady, "I'm in the picture!" (Ritchie 1971, 32) ("Ich bin im Bilde!” [Kaiser 1919, 36]). As H. J. Schueler suggests, "in identifying himself with Adam, Kassierer becomes representative of all men” (1984, 100). In his identification with the first man and comparison of the Lady with Eve, the Cashier makes explicit their participation in a temptation and fall narrative. Death appears to the Cashier in the field, a kind of summoning of Everyman, a call to reckoning; like Everyman, the Cashier requests just a bit more time to find something or someone to bring him to redemption. Like Jedermann, he at first wastes the additional time he has been granted seeking out worthless companionship. His mistake seems more understandable, however, since unlike Elckerlijc/Everyman/ Jedermann he is never told that Goods have damned and will damn him. He therefore takes his money with him, not personified as Goods or as Mammon (both as characters could speak and enlighten the Cashier about his error) but in the form of dumb objects, gold and paper money. Trying to buy his way into a secular heaven, he realizes too late that money has controlled and corrupted him.

The central moral message of Kaiser's play, then, the moral instruction one expects from a morality play, seems to be that competition and consumerism lead to exploitation and to the dehumanization of both the exploited and the exploiter. The Cashier who offers prize money to athletes (who then destroy their bodies for the entertainment of others) and the Cashier who offers money to destitute women in a nightclub (who sell their bodies for simple survival) is similarly controlled by money, made its subject, its puppet, and is also lost, purposeless, alone. Yet the Cashier has the ability to change his own fate. Like the central figure of the generic morality play in Clifford Davidson's description, the Cashier sees "his life as wounded and in need of healing, or as unnaturally separated from the sources of all health and well being" (1989, 11). The Cashier, however, is unaware how to proceed, how to make things better, like many in 
pre- and post-First World War Germany and Europe. To the Cashier's confusion, his play lacks a trustworthy character with access to truth, an equivalent of the characters Knowledge in Everyman and Faith in Jedermann: living in a postKantian world, a world in which God has become inaccessible (or in Nietzsche's expression, dead), the Cashier has no access to moral truths except those created, tested, and chosen by human beings. The Cashier in his peculiar dilemma is medievalist rather than medieval: he is an Expressionist Everyman who must in the end determine his own morality.

It would have been better perhaps if, like Elckerlijc/Everyman/Jedermann, the Cashier had earlier mobilized his Good Deeds instead of placing his trust in his Goods. What might constitute Expressionist Good Deeds in the play, however, is a challenging question. Given Landauer's influence on Kaiser, the Cashier's action of renouncing capital and discarding money as a mechanism of exchange, the modern equivalent of Elckerlijc/Everyman/Jedermann preferring and privileging spiritual actions over material wealth, might constitute the most important act a repentant Expressionist Everyman could take. Landauer believed that individuals freed from the capitalist drive to compete, acquire, and consume would again recognize and fulfil their artistic and spiritual potentials. The best deed, then, would be the choice to act to embrace organic, voluntary socialism. But to make that choice and to take that action, the Cashier as Everyman would need to join in community with like-minded individuals; he cannot act alone. Even two individuals would be enough to realize this ideal, as the Cashier tells the Salvation Army Girl. "Masses left behind us? Crowd dispersed. [...] Maid and Man. Ancient gardens re-opened. Cloudless sky. Voice from the silence of the tree-tops. All is well. (Drum roll.) Maid and man - eternal constancy. Maid and man - fullness in the void - beginning and end - seed and flower - sense and aim and goal." (Ritchie 1971, 72.) ("Menschenscharen dahinten. Gewimmel verronnen. [...] Mädchen und Mann. Uralte Gärten aufgeschlossen. Entwölkter Himmel. Stimme aus Baumwipfelstille. Wohlgefallen. Wirbel. Mädchen und Mann - ewige Beständigkeit. Mädchen und Mann - Fülle im Leeren. Mädchen und Mann - vollendeter Anfang. Mädchen und Mann - Keim und Krone. Mädchen und Mann - Sinn und Ziel und Zweck.” [Kaiser 1919, 117-118.])

After discovering the Salvation Army Girl's betrayal, however, the Cashier loses hope, stating, "here I stand. I stand above you. Two are too many. There's space for one only. Loneliness is space; space is loneliness" (Ritchie 1971, 72). ("Hier stehe ich. Oben stehe ich. Zwei sind zuviel. Der Raum faßt nur einen. Einsamkeit ist Raum. Raum ist Einsamkeit” [Kaiser 1919, 118].) In Elckerlijc, 
Everyman, and Jedermann, a maid and a man step together into the grave at the end of the central characters' journeys, as Good Deeds in all three plays is gendered female. The Cashier in From Morning to Midnight meets death alone. Finding himself without a community, he commits suicide to avoid becoming trapped once again in the capitalist system he has renounced.

After their deaths, an Angel appears to collect Elckerlijc's, Everyman's, and Jedermann's souls and/or describes their arrival in heaven. In contrast, in From Morning to Midnight, no angel appears, only a Policeman (Schutzmann), who comments after the Cashier's death and in response to an explosion of lightbulbs in the chandelier above his head, "there must have been a short circuit" (Ritchie 1971, 73). ("Es ist ein Kurzschluß in der Leitung” [Kaiser 1919, 120].) From the perspective of another functionary of the state, the Cashier's decision to opt out of a corrupt system and the action he takes to effect his escape are nothing more than evidence of a minor systemic flaw; they do not signify individual moral agency or value. Yet the Cashier's act may still represent a kind of redemption. As Schueler observes, the Cashier at the beginning of the play discovers his identity as Adam; he then experiences a "fortunate fall" which should prepare the way for his salvation. This salvation cannot be brought about by God's intervention, by Christ's salvific sacrifice as the Second Adam - not in an Expressionist world. Therefore the Cashier "takes it upon himself to accomplish the task of his own and mankind's redemption” (Schueler 1984, 101). In Schueler's opinion, the Cashier fails to redeem himself and others because of his self-deification, his attempt to take on a Christ-like role (102); in attempting to make himself divine, the Cashier succeeds only in isolating himself (102-103). However, the reverse in fact seems true: the Cashier's isolation, his betrayal by the Salvation Army Girl and the others at the meeting and ultimately his failure to achieve community through the expression of Geist, precedes his suicide; his isolation drives him to act in a God-like way by choosing Death and by making Death his servant rather than helplessly answering Death's call.

The medievalism of Kaiser's From Morning to Midnight becomes more apparent when the play is compared with Karl Heinz Martin's experimental film version of the text produced in 1920. Martin had already produced Kaiser's play for the Hamburg Thalia Theatre in 1918 (Kasten 2003, 153) and gained considerable fame in Expressionist circles with his direction of the 1919 Berlin premiere of Ernst Toller's play The Transfiguration (Die Wandlung). According to Cynthia Walk, Martin in his screen adaptation of Kaiser's text attempted to build on his previous stage success by "importing the project of theatrical expressionism into film" 
(Walk 2007, 185). In the process, Martin deemphasized the play's medievalism, making the film's aesthetic and generic allusions more contemporary. Jurgen Kasten argues the film appropriates Expressionist painting and graphic design in its two-dimensional sets (see also Walk 2007, 184), while Walk expands this argument, proposing the film exhibits more complex "cross-media" exchanges. She points out that the film's incorporation of visual art conventions "came via the theatre" $(2007,184)$; therefore the role contemporary scenography played "in mediating the style of the film decor" requires consideration $(2007,184)$. In her evaluation, the film is "neither filmed theatre nor simply derivative theatrical expressionism" (2007, 185); neither is it exclusively "high-culture art" (2007, 186). Walk argues that "the Cashier's story [in Martin's film] is adapted to the conventions of the detective film, the most popular serial film genre of the postwar period" $(2007,186)$. This adaptation overwrites and overwhelms all traces of the morality play found in Kaiser's text.

The film no longer dramatizes temptation, sin, and repentance but instead presents "a proto-typical five-act crime scenario, representing 1) crime, 2) discovery, 3) escape, 4) chase, and 5) capture” (Walk 2007, 186). The Cashier's fall is not compared to Adam's; the painting purchased by the Lady and her Son is a contemporary abstract female nude, not a lost medieval painting by Cranach depicting Adam and Eve together in the Garden of Eden. [Fig. 1.] Assuming that the painting is a portrait, the Cashier asks the Lady, "Is that you?" ("Das sind Sie?"), inquiring if she is the naked, headless woman reclining in the image. Martin's Lady, then, is not Eve, is more likely the familiar character of the cinematic vamp; exotically dressed and (like the image in the painting) visually overpowering, the Lady inspires the Cashier to commit a crime, unintentionally seducing and disempowering him, precipitating his fall. The Cashier propositions the Lady only to discover that she is not a criminal impostor nor someone who can be bought. The Lady, overwhelmed by their confrontation in her hotel room, faints across a settee. Before leaving, the Cashier sees the figure of the prone (and in his imagination, partially naked and headless) Lady posed and positioned as though she is the abstract nude figure in the painting, presented as a tantalizing commodity for purchase or an object to be taken by force. [Fig. 2.] The Cashier can do neither, cannot act on his desire. He flees and for the remainder of the film moves from place to place more to avoid capture than to find fulfilment, having experienced no spiritual enlightenment. In Kaiser's play, the police appear only at the very end; in Martin's film, cross-cut scenes juxtapose the Cashier with officers in hot pursuit as he moves through the city, attempting to throw them off 
his trail. The Cashier's realization that the money he has stolen has no intrinsic value is present in the film but appears to have specific contextual and historical meaning: post-World War One inflation is obviously referenced. Walk describes a close up early in the film of banknotes "marked only with zeros" signifying "the emptiness of currency devalued to nothing" in the Weimar Republic $(2007,187)$. In the world of the film, the Cashier does not appear to realize that consumerism creates disconnection between individuals, opening the way to their exploitation. The film itself does not clearly condemn or even comment on the Cashier's mistreatment of his family, the cyclists, or the dancers in the nightclub.

Finally, the play's and the film's representations of death are very different. In Kaiser's play, Death first appears to the Cashier in a tree in the frozen field at the end of part one. Death does not reappear until the play's final moments, in the chandelier, when the Cashier chooses to commit suicide. In the film, Death does not appear at these moments or in these objects; instead, like the police Death chases the Cashier from place to place, appearing repeatedly within the action, seeming to catch up with and capture the Cashier at the Salvation Army meeting. As the plot unfolds, a death's head appears through the use of a cinematic dissolve over the faces of a number of female characters encountered by the Cashier as he moves through the city: a Beggar Woman outside the hotel, his Daughter as she tries to prevent him from leaving the family home, a Prostitute outside the sports complex, the Dancer with the wooden leg inside the nightclub, and the Salvation Army Girl moments before she betrays him to the police upon learning he has a bounty on his head. [Fig. 3.] Death in the play is gendered male; Death in the film is obviously gendered female. Further, the film seems to support the Cashier's rejection and suspicion of the women through whom Death manifests: these women all appear to represent authentic economic, social, physical, and sexual threats. Walk suggests the film participates in a "discourse of castration” prevalent in 1920s German cinema $(2007,187)$. Described by Richard W. McCormick, this discourse betrays an obsession "with the supposed loss of male power and authority" in post-war Germany, an obsession precipitated by the equation of "German national identity with manhood" and by changing traditional gender roles in the Weimar Republic (McCormick 2001, 25). Women's suffrage, constitutional equality, and increased presence in the workforce marked the early years of the Republic, bringing about a "crisis of traditional male authority, agency, and identity" (3). Again, the film's references are primarily historically contextual. The Cashier's suicide at the end of the film therefore reads very differently than his suicide at the end of the play. In the film, Death 
seems less a choice than something the Cashier cannot escape, a necessary effect of his particular historical circumstance. He dies alone, but community in the world of the film, more so even than in the play, seems impossible. In Kaiser's play, the simplest of communities, "Maid and Man," is represented in Cranach's painting of Adam and Eve. In contrast, in Martin's film, the painting represents the individual alone, abstracted - and female. In post-World War One Germany, the male Cashier finds - or rather feels - himself to be excluded and superfluous.

Both versions of From Morning to Midnight express the plight of a modernist subject searching for and failing to find fulfilment. However, the medievalism of Kaiser's play works to create the impression its moral insights and instruction have a longer history, applying across centuries of human experience and across cultures. At the same time they are contemporary and provide a modern perspective on familiar human anxieties and challenges. Unlike the earlier Everyman characters in the morality play genre, the Cashier in the end fails to find redemption and connection. Death, a non-speaking role in Kaiser's play, unlike in its earlier generic counterparts, personifies only human knowledge of mortality - he is not presented as the agent of (a non-existent) God. The play's metaphysics differ radically from Elckerlijc's, Everyman's, and Jedermann's, but their central problems, medieval and modernist, are similar. All four texts ask how redemption might be achieved. Kaiser's play modifies the generic morality form of the other texts to dramatize a contemporary protagonist's failure to achieve salvation. But the text does not therefore contend that salvation is unachievable. It rather demonstrates that salvation is more difficult to achieve than earlier morality plays might suggest, and that it is impossible to realize beyond this world and outside of human community. In this way, Kaiser's play differs from Karl Heinz Martin's film adaptation, which presents a narrower focus on postWorld War One Germany, offering a much bleaker, gendered view of a particular community challenged by past and present crisis and change.

\section{References}

Artaud, Antonin. 1961. Manifeste pour un théâtre avorté [Manifesto for a Theatre that Failed]. In Ouevres Complètes [Collected Works], vol. II, 22-25. Paris: Gallimard.

Antonin Artaud 1988 [1976]. Manifesto for a Theatre That Failed. In Antonin Artaud: Selected Writings, ed. Susan Sontag, 159-162. Berkeley: University of California Press. 
Conley, John. 1985. Preface. In The Mirror of Everyman's Salvation: a prose translation of the original Everyman, eds. John Conley, Guido de Baere, H. J. C. Schaap, and W. H. Toppen, 7-13. Amsterdam: Rodopi.

Davidson, Clifford. 1989. Visualizing the Moral Life: Medieval Iconography and the Macro Morality Plays. New York: AMS Press.

Davidson, Clifford, Martin W. Walsh, and Ton J. Broos, eds. 2007. Everyman and Its Dutch Original, Elckerlijc. Kalamazoo, MI: Medieval Institute Publications. Flavell, M. Kay. 1988. George Grosz: A Biography. New Haven: Yale University Press.

Goebel, Stefan 2008. Great War and Medieval Memory: War, Remembrance, and Medievalism in Britain and Germany, 1914-1940. Cambridge: Cambridge University Press.

Henze, Wolfgang. 2007. The Sculptures of Kirchner, Scherer, Müller, and Wiegers. In Ernst Ludwig Kirchner and Friends: Expressionism from the Swiss Mountains, eds. Beat Stutzer, Samuel Vitali, Han Steenbruggen, and Matthias Frehner, 142-169. Zürich: Scheidegger \& Spiess.

Hofmannsthal, Hugo von. 1957. Jedermann: Das Spiel vom Sterben des Reichen Mannes. In Gesammelte Werke: Dramen III [Collected Works: Plays III] 7-93. Frankfurt: S. Fischer.

Kaiser, Georg. 1919. Von morgens bis mitternachts [From Morning to Midnight]. Berlin: S. Fischer.

Kasten, Jurgen. 2003. On Karl Heinz Martin's From Morn to Midnight. In Expressionist Film: New Perspectives, ed. Dietrich Scheunemann, 157-172. New York: Camden House.

King, Pamela. 2008. Morality Plays. In The Cambridge Companion to Medieval English Theatre, eds. Richard Beadle and Alan J. Fletcher, 235-262. Cambridge: Cambridge University Press.

Lambert, Carole Jane. 1986. Anti-Rationalism in Symbolist Drama: Medieval Themes, Circumstances, and Symbols in the Plays of Maurice Maeterlinck, Paul Claudel, August Strindberg, and Georg Kaiser. Unpublished PhD dissertation, comparative literature, University of California, Berkeley.

Martin, Karl Heinz, dir. 1920. Von morgens bis mitternachts. https://www. youtube.com/watch?v=87JUKRcXsFA. Last accessed 27. 04. 2018.

Maurer, Charles. 1971. Call to Revolution: The Mystical Anarchism of Gustav Landauer. Detroit: Wayne State University Press.

McCormick, Richard W. 2001. Gender and Sexuality in Weimar Modernity: Film, Literature, and "New Objectivity." New York: Palgrave. 
Potter, Robert. 1975. The English Morality Play: Origins, History and Influence of a Dramatic Tradition. London and Boston: Routledge \& Kegan Paul.

Ritchie, J. M., ed. 1971. From Morning to Midnight. In Five Plays: Georg Kaiser, 17-73. London: Calder and Boyars.

Schreiber, Earl G. 1975. Everyman in America. Comparative Drama vol. 9, no. 2 : 99-115.

Schueler, H. J. 1984. The Symbolism of Paradise in Georg Kaiser's Von Morgens bis Mitternachts. Neophilologus no. 68: 98-104.

Speaight, Robert. 1954. William Poel and the Elizabethan Revival. Melbourne, London, and Toronto: William Heinemann Ltd.

Stevens, Martin. 1973. The Reshaping of Everyman: Hofmannsthal at Salzburg. The Germanic Review vol. 48, no. 2: 117-131.

Walk, Cynthia. 2007. Cross-Media Exchange in Weimar Culture: Von morgens bis mitternachts. Monatshefte vol. 99, no. 2: 177-193.

Williams, Rhys. 1988. Culture and Anarchy in Georg Kaiser's 'Von morgens bis mitternachts.' The Modern Language Review vol. 83, no. 2: 364-374.

\section{List of Figures}

Figure 1. Karl Heinz Martin, Von morgens bis mitternachts (1920).

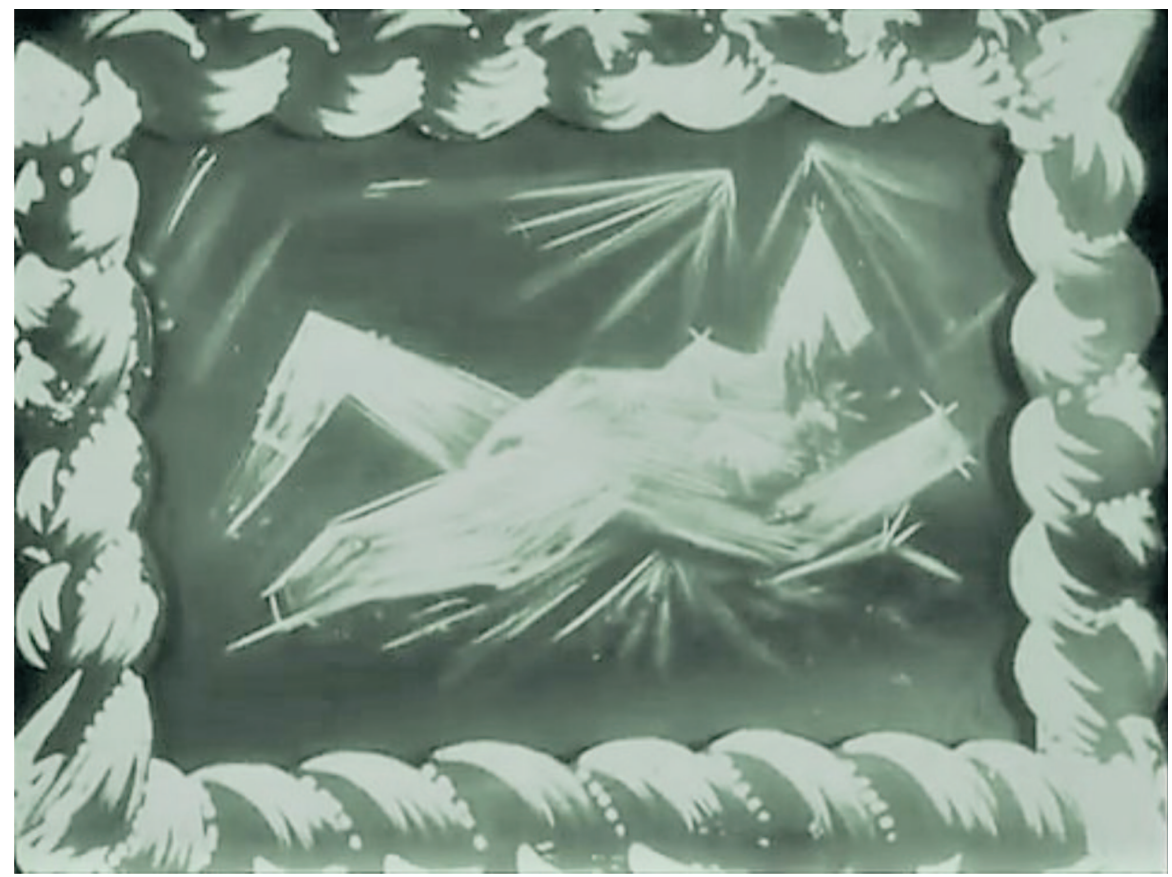


Figure 2. Karl Heinz Martin, Von morgens bis mitternachts (1920).

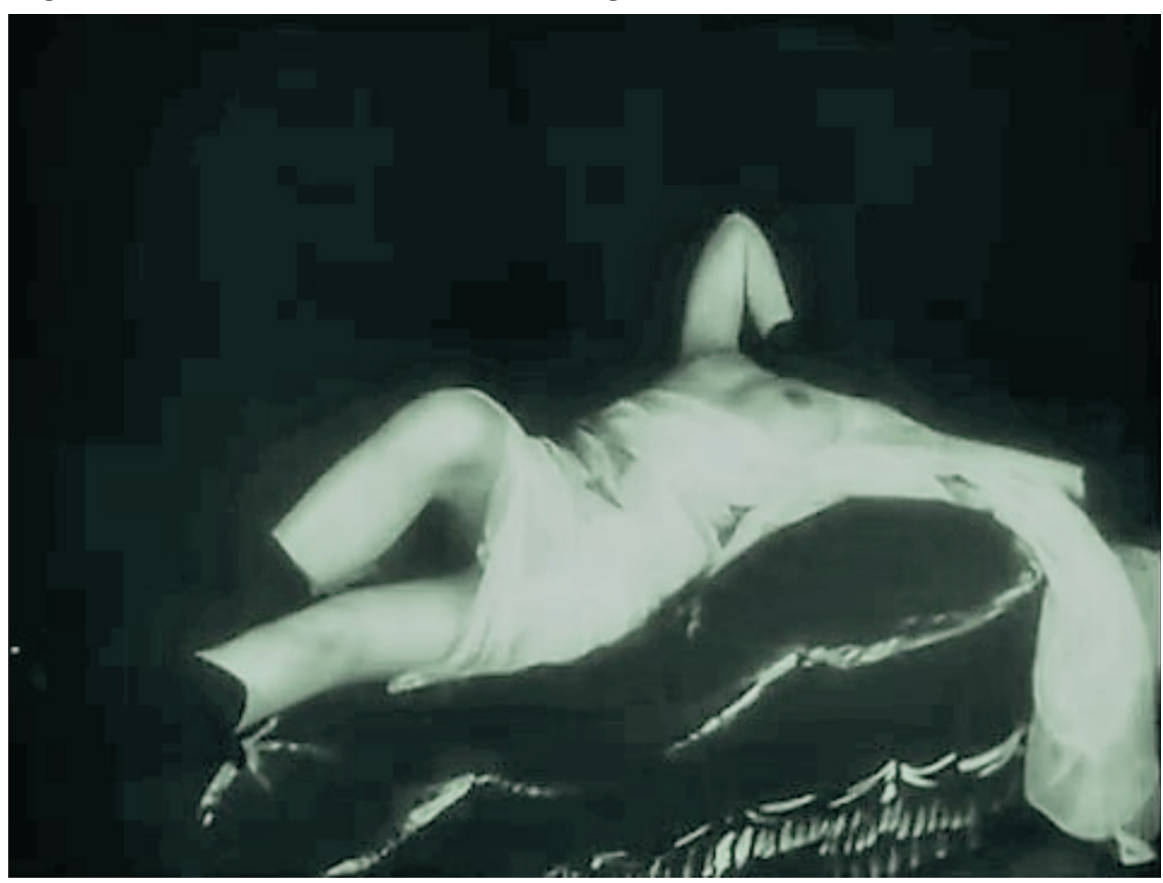

Figure 3. Karl Heinz Martin, Von morgens bis mitternachts (1920).

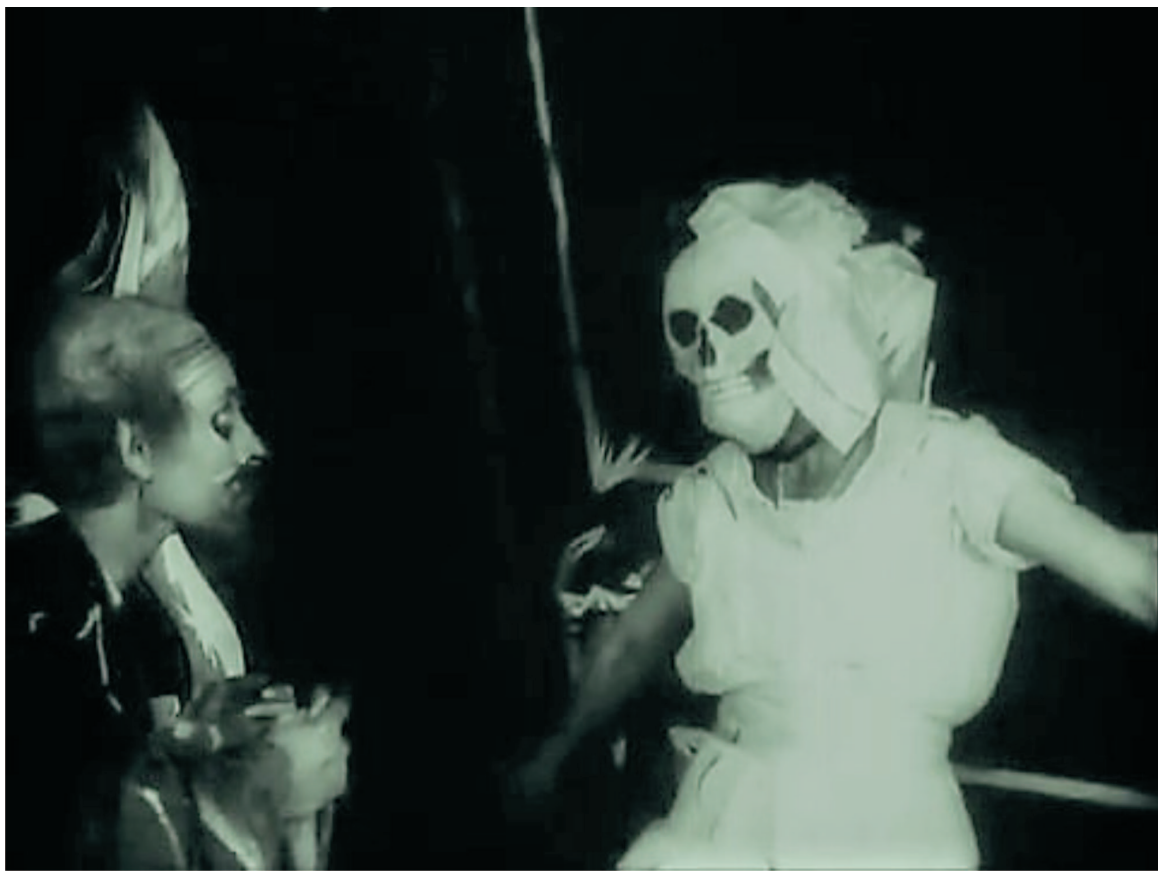

